\title{
Dacrymenone and VM 3298-2 - New Antibiotics with Antibacterial and Antifungal Activity ${ }^{\S}$
}

\author{
Viktor Mierau ${ }^{\mathrm{a}}$, Timm Anke $\mathrm{a}^{\text {* }}$, and Olov Sterner ${ }^{\mathrm{b} *}$ \\ a Lehrbereich Biotechnologie der Universität Kaiserslautern, Paul-Ehrlich-Str. 23, \\ D-67663 Kaiserslautern, Germany. Fax: +496312052999. E-mail: anke@rhrk.uni-kl.de \\ b Department of Organic and Bioorganic Chemistry, University of Lund, P. O. Box 124, \\ S-22100 Lund, Sweden. Fax +46462228209. E-mail: Olov.Sterner@bioorganic.lth.se \\ * Authors for correspondence and reprint requests \\ Z. Naturforsch. 58c, 541-546 (2003); received March 21/May 15, 2003
}

Two new antibiotic metabolites, dacrymenone (1) and VM 3298-2 (2), were isolated from fermentations of a Dacrymyces $s p$., and their structures were determined by spectroscopic techniques. Dacrymenone (1) is a new eremophilane sesquiterpenoid while VM 3298-2 (2) is a bis-enol ether between methyl pyruvate and 4,6-dihydroxycyclohexan-1,3-dione. Dacrymenone (1) shows weak antibacterial and antifungal activity while VM 3298-2 (2) exhibits cytotoxic and antifungal activities.

Key words: Antifungal Antibiotic, Eremophilanes, Dacrymyces

\section{Introduction}

Dacrymyces species are small in many cases brightly yellow or orange coloured fungi frequently found on decaying wood of deciduous trees or conifers. Up to now not much is known of their secondary metabolism and their products. In one of our previous screenings we isolated an antifungal compound from Dacrymyces stillatus which turned out to be identical to glykenin IV A, produced by an unclassified basidiomycete (Wunder, 1995; Nishida F. et al., 1991; Nishida F. et al., 1994). In the course of a screening for antibiotics against Candida species another strain of Dacrymyces was found to produce compounds not related to the glykenins. In the following we wish to describe the fermentation, isolation, biological characterization, and structure elucidation of two new antibiotics from Dacrymyces sp. 32-98.

\section{Material and Methods}

Dacrymyces sp. 32-98

Dacrymyces sp. 32-98 was collected in La Réunion, France. The bright orange resupinate fruiting bodies were growing on wood causing an intensive white rot. The gelatinous basidiocarps showed all characteristics of the genus e.g. bifur-

$\S$ This paper is dedicated to the memory of the late Professor Udo Gräfe, Hans-Knöll-Institut, Jena. cate basidia and allantoid, transversely septate 4 celled basidiospores. The species, however could not be identified. Mycelial cultures of strain 32-98 were derived from spores. For maintenance on agar slants the fungus was grown on YMG medium (g/l): yeast extract 4 , malt extract 10 , glucose 4, $\mathrm{pH}$ 7.0. Culture and herbarium specimen are deposited in the culture collection of the LB Biotechnologie, Universität Kaiserslautern.

\section{Fermentation and isolation of dacrymenone (1) and VM 3298-2 (2)}

Fermentation was carried out in 20 liters of malt medium composed of $(\mathrm{g} / \mathrm{l})$ : malt extract $40, \mathrm{pH} 5.5$ in a Biolafite $\mathrm{C} 6$ fermenter at $22^{\circ} \mathrm{C}$ with aeration $(2.5 \mathrm{l} / \mathrm{min})$ and agitation $(120 \mathrm{rpm})$. A well-grown culture $(250 \mathrm{ml})$ in the same medium was used as inoculum. During fermentation $100 \mathrm{ml}$ samples were taken. The culture fluid was separated by filtration from the mycelia and then extracted with an equal volume of ethyl acetate. The residue obtained after evaporation of the organic solvent was taken up in $0.5 \mathrm{ml}$ of methanol. $25 \mu \mathrm{l}$ of the concentrated solutions were assayed for antifungal and antibacterial activity in the agar plate-paper disc diffusion assay using Nematospora coryli, Candida krusei and Bacillus brevis as test organisms. After 14 days of fermentation when the antibiotic activity had reached the maximum the cul- 
ture fluid was separated from mycelia and passed through a column containing Mitsubishi Diaion HP $21(30 \times 5.5 \mathrm{~cm})$ adsorber resin. The column was washed with $\mathrm{H}_{2} \mathrm{O}$ then methanol/ $\mathrm{H}_{2} \mathrm{O}(1: 1)$, methanol and finally with acetone. The methanol/ $\mathrm{H}_{2} \mathrm{O}$ eluate was concentrated and the crude product $(1.95 \mathrm{~g})$ was applied onto a Sephadex LH 20 column $(64 \times 1.6 \mathrm{~cm})$ and eluted with methanol. The antibiotic containing fractions were pooled (730 mg) and applied to a silica gel column (Merk $60.6 \times 2.5 \mathrm{~cm})$. Elution with cyclohexane-ethyl acetate 1:9 yielded $172 \mathrm{mg}$ containing 2 . Final purification was achieved by preparative HPLC on Nucleosil RP18 $(7 \mu \mathrm{m}$; column $250 \times 21.2 \mathrm{~mm}$; flow $5 \mathrm{ml} / \mathrm{min}$ ). Elution with water-methanol 85:15 v/v yielded $22 \mathrm{mg}$ VM 3298-2 (2) (for structures see Fig. 2).

The crude product of the acetone eluate (393 mg) was directly applied to a silica gel column (Merk 60, 0.063-0.2 mm, $12 \times 2.5 \mathrm{~cm}$ ). Elution with ethyl acetate yielded $84 \mathrm{mg}$ of an enriched product. Final purification was achieved by preparative HPLC on Nucleosil RP18 ( $7 \mu \mathrm{m}$; column $250 \times 21.2 \mathrm{~mm}$; flow: $5 \mathrm{ml} / \mathrm{min})$. Elution with water-methanol 40:60 v/v yielded $12 \mathrm{mg}$ of dacrymenone (1).

\section{Analytical methods}

For analytical HPLC a Hewlett Packard 1100 series instrument was used and for preparative HPLC a Gilson Model 302 (Abimed, Langenfeld) with variable UV-Detector (Knauer, Bad Homburg). UV and IR spectra were recorded with a Perkin Elmer $\lambda 16$ and a Bruker IFS 48 spectrometer. ${ }^{1} \mathrm{H}$ NMR $(500 \mathrm{MHz})$ and ${ }^{13} \mathrm{C}$ NMR $(125 \mathrm{MHz})$ were recorded at room temperature with a Bruker DRX500 spectrometer with an inverse multinuclear $5 \mathrm{~mm}$ probehead equipped with a shielded gradient coil. The spectra were recorded in $\mathrm{CDCl}_{3}$ (1) and $\mathrm{CDCl}_{3}: \mathrm{CD}_{3} \mathrm{OD} 1: 1$ (2), and the solvent signals (7.26/77.0 and 3.31/39.51 ppm, respectively) were used as reference. The chemical shifts $(\delta)$ are given in ppm, and the coupling constants $(J)$ in Hz. COSY, HMQC and HMBC experiments were recorded with gradient enhancements using sine shaped gradient pulses. For the 2D heteronuclear correlation spectroscopy the refocusing delays were optimised for ${ }^{1} J_{\mathrm{CH}}=145 \mathrm{~Hz}$ and ${ }^{\mathrm{n}} J_{\mathrm{CH}}=$ $10 \mathrm{~Hz}$. The raw data were transformed and the spectra were evaluated with the standard Bruker XWIN-NMR software (rev. 010101). Mass spectra were recorded with a LC-MS (HP 1100; APCI, positive and negative mode) and a Jeol SX102 spectrometer (HREIMS, HRCIMS and FABMS spectra). The optical rotations were measured with a Perkin-Elmer 141 polarimeter at $22^{\circ} \mathrm{C}$.

Dacrymenone (1) was obtained as a colourless oil. $[\alpha]_{\mathrm{D}}^{22}+80^{\circ}\left(c 0.1\right.$ in $\left.\mathrm{CHCl}_{3}\right)$. UV $\lambda$ max $234 \mathrm{~nm}$ (log $\varepsilon$ 3.59). IR (KBr): 3430, 2925, 1735, 1675, 1375, 1246 and $1035 \mathrm{~cm}^{-1}$. ${ }^{1} \mathrm{H}$ NMR $(500 \mathrm{MHz}$, $\left.\mathrm{CDCl}_{3}\right) \delta 5.84\left(1 \mathrm{H}, \mathrm{d}, J_{1 \mathrm{~b}-9}=1.7,9-\mathrm{H}\right), 5.00(1 \mathrm{H}$, s, 12-Ha), $4.92\left(1 \mathrm{H}, \mathrm{dd}, J_{2-3}=9.4, J_{3-4}=11.1\right.$, $3-\mathrm{H}), 4.82(1 \mathrm{H}, \mathrm{s}, 12-\mathrm{Hb}), 3.66\left(1 \mathrm{H}, \mathrm{ddd}, J_{1 \mathrm{a}-2}=\right.$ $\left.5.4, J_{1 \mathrm{~b}-2}=12.0, J_{2-3}=9.4,2-\mathrm{H}\right), 3.13(1 \mathrm{H}, \mathrm{dd}$, $\left.J_{6 \mathrm{a}-7}=4.5, J_{6 \mathrm{~b}-7}=14.4,7-\mathrm{H}\right), 2.68(1 \mathrm{H}, \mathrm{dd}$, $\left.J_{1 \alpha-1 \beta}=14.4, J_{1 \mathrm{a}-2}=5.4,1-\mathrm{Ha}\right), 2.52(1 \mathrm{H}, \mathrm{ddd}$, $\left.J_{1 \alpha-1 \beta}=14.4, J_{1 \mathrm{~b}-2}=12.0, J_{1 \mathrm{~b}-9}=1.7,1-\mathrm{Hb}\right), 2.16$ $(3 \mathrm{H}, \mathrm{s}, 3-\mathrm{OAc}), 2.02\left(1 \mathrm{H}, \mathrm{dd}, J_{6 \mathrm{a}-6 \mathrm{~b}}=13.1, J_{6 \mathrm{a}-7}=\right.$ $4.5,6-\mathrm{Ha}), 1.85\left(1 \mathrm{H}, \mathrm{dd}, J_{6 \mathrm{a}-6 \mathrm{~b}}=13.1, J_{6 \mathrm{~b}-7}=14.4\right.$, $6-\mathrm{Hb}), 1.74\left(3 \mathrm{H}, \mathrm{s}, 13-\mathrm{H}_{3}\right), 1.57\left(1 \mathrm{H}, \mathrm{dq}, J_{3-4}=\right.$ $\left.11.1, J_{4-15}=6.8,4-\mathrm{H}\right), 1.27\left(3 \mathrm{H}, \mathrm{s}, 14-\mathrm{H}_{3}\right), 0.95$ $\left(3 \mathrm{H}, \mathrm{d}, J_{4-15}=6.8,15-\mathrm{H}_{3}\right) \cdot{ }^{13} \mathrm{C}$ NMR $(125 \mathrm{MHz}$, $\left.\mathrm{CDCl}_{3}\right) \delta 198.1(\mathrm{C}-8), 171.9(\mathrm{C}=\mathrm{O}, 3-\mathrm{OAc}), 163.4$ (C-10), 143.0 (C-11), 126.0 (C-9), 114.5 (C-12), 78.0 (C-3), 72.4 (C-2), 50.3 (C-7), 44.9 (C-4), 41.5 (C-6), 39.7 (C-5), $21.0\left(\mathrm{CH}_{3}, 3-\mathrm{OAc}\right), 20.1$ (C-13), 17.1 (C-14), 10.2 (C-15). EIMS m/z 292,1668 (8 \%, $\mathrm{M}^{+}, \mathrm{C}_{17} \mathrm{H}_{24} \mathrm{O}_{4}$ requires 292,1675), 274 (33\%), 232 (100\%), 214 (45\%), 186 (21\%), 172 (13\%), 145 (35\%), 119 (17\%), 44 (61\%), 43 (79\%).

VM 3298-2 (2) was obtained as a colourless oil. $[\alpha]_{\mathrm{D}}^{22}+12^{\circ}\left(c 0.9\right.$ in $\left.\mathrm{CH}_{3} \mathrm{OH}\right)$. UV $\lambda_{\max }^{\mathrm{MeOH}} 243 \mathrm{~nm}$ ( $\log \varepsilon$ 3.90). IR (KBr): 3420, 1735, 1675, 1610, 1440, 1360, 1315, 1200, 1160, 1120 and $1080 \mathrm{~cm}^{-1} .{ }^{1} \mathrm{H}$ NMR (500 MHz, $\left.\mathrm{CDCl}_{3}: \mathrm{CD}_{3} \mathrm{OD} 1: 1\right) \delta 6.16(1 \mathrm{H}, \mathrm{d}$, $\left.J_{8 \mathrm{a}-8 \mathrm{~b}}=2.0,8-\mathrm{Ha}\right), 5.65\left(1 \mathrm{H}, \mathrm{d}, J_{8 \mathrm{a}-8 \mathrm{~b}}=2.0,8-\mathrm{Hb}\right)$, $5.25\left(1 \mathrm{H}, \mathrm{d}, J_{2-6}=1.2,2-\mathrm{H}\right), 4.73\left(1 \mathrm{H}, \mathrm{ddd}, J_{2-6}=\right.$ $\left.1.2, J_{5 \mathrm{a}-6}=5.2, J_{5 \mathrm{~b}-6}=10.7,6-\mathrm{H}\right), 4.11\left(1 \mathrm{H}, \mathrm{dd}, J_{4-}\right.$ $\left.5 \mathrm{a}=5.2, J_{4-5 \mathrm{~b}}=13.1,4-\mathrm{H}\right), 3.79\left(3 \mathrm{H}, \mathrm{s}, 10-\mathrm{H}_{3}\right), 2.66$ $\left(1 \mathrm{H}, \mathrm{ddd}, J_{4-5 \mathrm{a}}=5.2, J_{5 \mathrm{a}-5 \mathrm{~b}}=12.0, J_{5 \mathrm{a}-6}=5.2,5-\right.$ Ha), $1.90\left(1 \mathrm{H}, \mathrm{ddd}, J_{4-5 \mathrm{~b}}=13.1, J_{5 \mathrm{a}-5 \mathrm{~b}}=12.0\right.$, $\left.J_{5 \mathrm{~b}-6}=10.7, \quad 5-\mathrm{H} \beta\right) .{ }^{13} \mathrm{C} \quad \mathrm{NMR} \quad(125 \mathrm{MHz}$, $\left.\mathrm{CDCl}_{3}: \mathrm{CD}_{3} \mathrm{OD} 1: 1\right) \delta 199.6(\mathrm{C}=3), 177.7(\mathrm{C}-1)$, 162.2 (C-9), 146.7 (C-7), 116.0 (C-8), 103.2 (C-2), 71.0 (C-4), 66.1 (C-6), 53.3 (C-10), 39.5 (C-5). EIMS $m / z \quad 210,0535\left(10 \%, \mathrm{M}^{+}-\mathrm{H}_{2} \mathrm{O}, \mathrm{C}_{10} \mathrm{H}_{10} \mathrm{O}_{5}\right.$ requires 210.0528), 196 (14\%), 184 (72\%), 152 (100\%), 141 (7\%), 124 (23\%), 113 (10\%), 99 (12\%), 97 (11\%), 69 (17\%). CIMS (methane) $\mathrm{m} / z$ 229,0711 (10\%, 
$\mathrm{M}^{+}+\mathrm{H}, \quad \mathrm{C}_{10} \mathrm{H}_{13} \mathrm{O}_{6}$ requires 229,0712). FABMS (without added $\mathrm{NaOAc}) \mathrm{m} / z, 229 \quad\left(\mathrm{M}^{+}+\mathrm{H}\right.$, $\mathrm{C}_{10} \mathrm{H}_{13} \mathrm{O}_{6}$ ). FABMS (with added NaOAc) $m / z, 251$ $\left(\mathrm{M}^{+}+\mathrm{Na}, \mathrm{C}_{10} \mathrm{H}_{12} \mathrm{O}_{6} \mathrm{Na}\right)$.

\section{Biological tests}

The assays for antimicrobial (Anke et al., 1989) and cytotoxic activities (Zapf et al., 1995) were carried out as described previously. Hela S3 (ATCC CCL 2.2 human cervix carcinoma) were grown in DMEM-medium, L1210 (ATCC CCL 219 mouse lymphocytic leukemia) Colo-320 (DSMZ ACC-144 human colon adenocarcinoma), HL-60 (ATCC CCL 240 human promyelocytic leukemia) in RPMI with $10 \%$ of foetal calf serum. All media contained $65 \mu \mathrm{g} / \mathrm{ml}$ of penicillin $\mathrm{G}$ and $100 \mu \mathrm{g} / \mathrm{ml}$ of streptomycin sulphate. The cells were incubated at $37^{\circ} \mathrm{C}$ in a humidified atmosphere containing $5 \% \mathrm{CO}_{2}$. Viable cells were counted after $24 \mathrm{~h}$. The incorporation of $\left[8-{ }^{14} \mathrm{C}\right]$-adenine (2 GBq/mmol), $\left[1-{ }^{14} \mathrm{C}\right]$-uridine $(1.96 \mathrm{GBq} / \mathrm{mmol})$, [1- $\left.{ }^{14} \mathrm{C}\right]$-leucine $(2 \mathrm{GBq} / \mathrm{mmol})$ und $\mathrm{N}$-acetyl-D-

$\left[1-{ }^{14} \mathrm{C}\right]$-glucosamine $(0.74 \mathrm{GBq} / \mathrm{mmol})$ into DNA, RNA, proteins and chitin was assayed with Nematospora coryli. The fungus was grown at $27^{\circ} \mathrm{C}$ in malt medium until an OD 0.3-0.4 was reached. $5 \mathrm{ml}$ aliquots of cell suspension were preincubated for $15 \mathrm{~min}$ with or without VM 3298-2 (2) before the radioactive precursors $\left(3.7 \times 10^{9} \mathrm{~Bq}\right)$ were added. The cultures were incubated for $90 \mathrm{~min}$ at $27^{\circ} \mathrm{C}$ on a gyratory shaker $(120 \mathrm{rpm})$. After addition of $0.55 \mathrm{ml} 1 \mathrm{~N} \mathrm{NaOH}$, the ${ }^{14} \mathrm{C}$-adenine containing assay was incubated for $30 \mathrm{~min}$ to hydro- lyse RNA. Cold trichloroacetic acid was added to all assays and the $5 \%$ TCA insoluble precipitates collected on membrane filters. After drying the radioactivity was measured in a liquid scintillation counter

\section{Results and Discussion}

Fig. 1 shows a typical fermentation of Dacrymyces sp. 32-98. After $120-150 \mathrm{~h}$ when the antibiotic content in the culture fluid had reached its maximum, the fermentation was stopped and dacrymenone (1) and VM 3298-2 (2) were isolated from the culture fluid as described in the experimental section.

\section{Structural elucidation}

EI mass spectra suggested that the elemental composition of dacrymenone (1) is $\mathrm{C}_{17} \mathrm{H}_{24} \mathrm{O}_{4}$, and this was confirmed by the $1 \mathrm{D}$ NMR data. This would give the unsaturation index 6 , and as the NMR signals account for two carbonyl groups and two carbon-carbon double bonds dacrymenone (1) should have two rings. The ready loss of $m / z 18$ and $m / z, 60$ in the EI mass spectra indicated the presence of both a hydroxyl group and an acetoxy group, and again the NMR data supported the suggestions made by the MS data. COSY correlations established the spin system C-1/C-2/C-3/ C-4/C-15, and the HMBC correlations (see Fig. 3) from 14-H3 to C-4, C-5, C-6 and C-10 and from $1-\mathrm{H} 2$ to $\mathrm{C}-10$ established the first of the two rings. Both protons (12-H2) of the 1,1-disubstituted car-

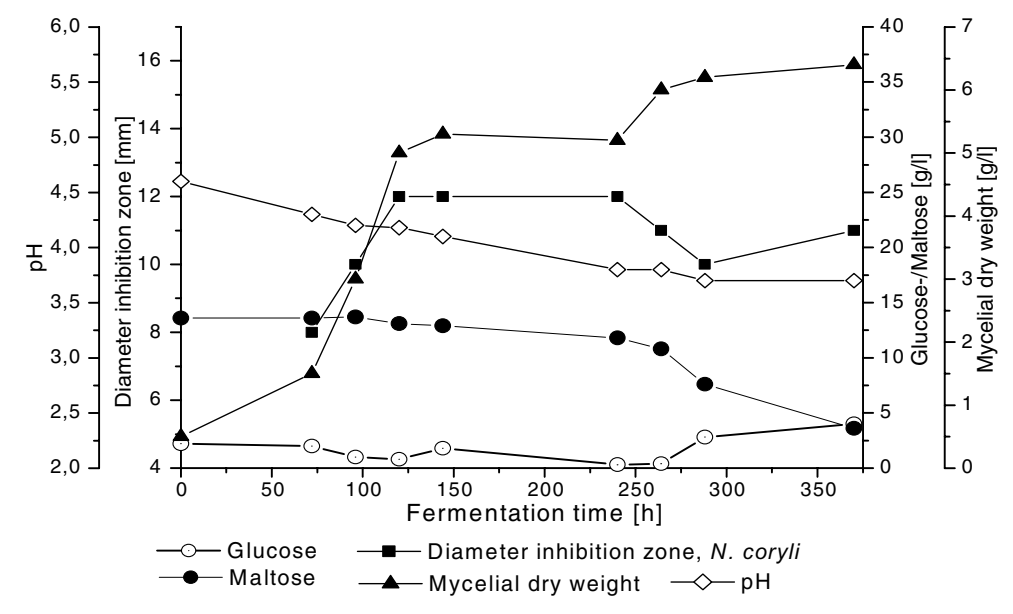

Fig. 1. Fermentation of Dacrymyces 3298; for conditions see experimental section. 


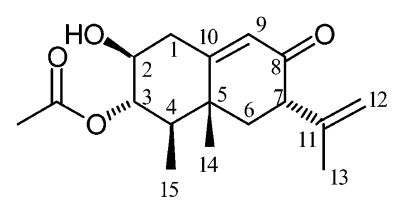

1<smiles>C=C(OC1=CC(=O)[C@@H](O)CC1O)C(=O)OC</smiles><smiles>C=C(C)[C@]12O[C@H]1[C@H]1C=C3CC[C@H](O)C(C)[C@@]3(C)C(=O)C=C1C2(C)C=O</smiles>

bon-carbon double bond as well as 13-H3 give HMBC correlations to $\mathrm{C}-7$, which is next to C-6 according to the ${ }^{1} \mathrm{H}-{ }^{1} \mathrm{H}$ couplings between their protons. 6- $\mathrm{H} 2$ and $7-\mathrm{H}$ also give $\mathrm{HMBC}$ correlations to the keto function (C-8), which must be situated on the other side of C-7. The only way to close the second ring is to insert C-9 between C-8 and $\mathrm{C}-10$, and this fits the HMBC correlations observed (see Fig. 3). The relative configuration of
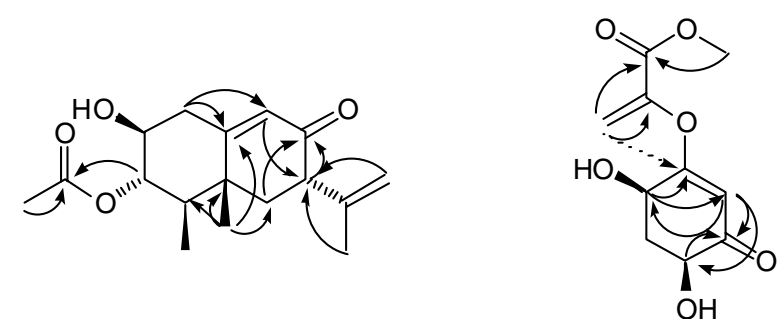

Fig. 3. Pertinent HMBC correlations observed with dacrymenone (1) (left) and VM 3298-2 (2) (right).
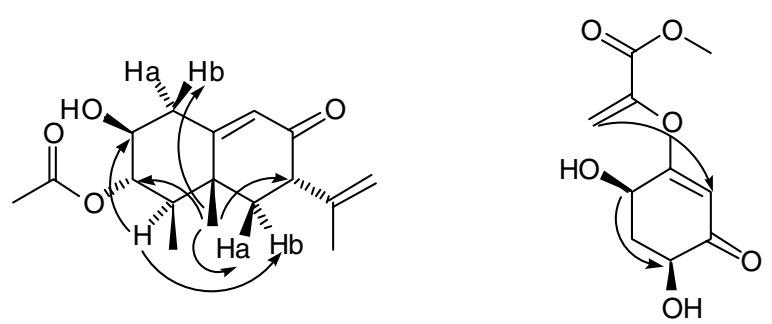

Fig. 4. Pertinent NOESY correlations observed with dacrymenone (1) (left) and VM 3298-2 (2) (right).<smiles>C=C(C)[C@H]1CC2(C)C(=CC1=O)CC[C@H](O)C2C</smiles>

Fig. 2. Structures of dacrymenone (1), VM 3298-2 (2), PR toxin (3), Sporogen A01 (4) and petasol (5).

dacrymenone (1) was established from NOESY data (summarized in Fig. 4) as well as from ${ }^{1} \mathrm{H}-$ ${ }^{1} \mathrm{H}$ coupling constants. The relative large coupling constants between $1-\mathrm{Hb}$ and $2-\mathrm{H}$, between $2-\mathrm{H}$ and $3-\mathrm{H}$, and between $3-\mathrm{H}$ and $4-\mathrm{H}$ suggest that the substituents on C-2, C-3 and C-4 all are equatorial, and NOESY correlations between $14-\mathrm{H}_{3}$ and $1-\mathrm{Hb}$ as well as $3-\mathrm{H}$ and between $2-\mathrm{H}$ and $4-\mathrm{H}$ confirmed this. $14-\mathrm{H}_{3}$ also give NOESY correlations to $6-\mathrm{Ha}$ and $7-\mathrm{H}$, while $6-\mathrm{Hb}$ correlates to $4-\mathrm{H}$, and the relative configuration of $\mathbf{1}$ must therefore be as suggested in Fig. 2.

Although the LC-MS data (positive ions) of VM 3298-2 (2) indicated that its molecular weight is 228 , this could not be confirmed by EIMS measurements because the molecule loses water too easily. However, with chemical ionisation (methane) the $\mathrm{M}+\mathrm{H}$ could be observed and the elemental composition of VM 3298-2 (2) could be determined to $\mathrm{C}_{10} \mathrm{H}_{12} \mathrm{O}_{6}$ by $\mathrm{HR}$ experiments. For confirmation, the mass spectra of VM 3298-2 (2) were also measured with FAB ionisation, and the expected $\mathbf{M}+\mathrm{H}(\mathrm{m} / \mathrm{z}, 229)$ was observed under normal conditions while $\mathrm{M}+\mathrm{Na}(\mathrm{m} / z$ 251) was observed when sodium acetate was added to the sample. The unsaturation index for VM 3298-2 (2) is consequently 5, and NMR signals accounting for two carbonyl groups and two carbon-carbon double bonds leave only one ring. This could be closed by the observation that H-6, part of the spin system $\mathrm{H}-4 / \mathrm{H}-5 / \mathrm{H}-6$, gives HMBC correlations to 
both $\mathrm{C}-1$ and $\mathrm{C}-2$, while $\mathrm{H}-4$ correlates to $\mathrm{C}-3$ and 2-H correlates to $\mathrm{C}-3, \mathrm{C}-4$ as well as $\mathrm{C}-6.8-\mathrm{H} 2$, the protons on the 1,1-disubstituted carbon-carbon double bond, give strong $\mathrm{HMBC}$ correlations to C-7 and C-9, but in addition a weak correlation can be observed to $\mathrm{C}-1$. A strong HMBC correlation from the methoxy protons $(10-\mathrm{H} 3)$ to $\mathrm{C}-9$ and a weak to $\mathrm{C}-8$ establish that the $\mathrm{C}-1$ substituent is the methyl ester of the enol of pyruvic acid. The link between C-1 and C-7, further supported by the NOESY correlation between $8-\mathrm{Ha}$ and $2-\mathrm{H}$, must be an oxygen (to satisfy the elemental composition), and $\mathbf{2}$ is therefore a bis-enol, and the chemical shifts are in agreement with this observation. The relative configuration of $\mathbf{2}$ was readily established, based on both a strong correlation between $4-\mathrm{H}$ and $6-\mathrm{H}$ in the NOESY spectrum as well as on the coupling constants that show that both protons are axial.

The antimicrobial activities of dacrymenone (1) and VM 3298-2 (2) are shown in Table I. Apart from the inhibitory effects on the Aspergillus ochraceus and Cladosporium cladosporioides, 1 inhibits the growth of bacteria at concentrations between $25-100 \mu \mathrm{g} / \mathrm{ml}(86-343 \mu \mathrm{M}) .2$ exhibits weak antifungal activity against yeasts and filamentous fungi, with the highest activity on Candida parapsilosis at $25 \mu \mathrm{g} / \mathrm{ml}(110 \mu \mathrm{M})$ and Saccharomyces cerevisiae at $10 \mu \mathrm{g} / \mathrm{ml}(44 \mu \mathrm{M})$. The eremophilane PR Toxin (3) from Penicillium roquefortii was reported to exhibit strong cytotoxic, fungicidal and bactericidal properties (Moulé et al., 1977). The greatly reduced biological activities of dacrymenone (1) are likely to be due to the lack of the aldehyde group and the two oxirane rings present in PR toxin. While no cytotoxic activities of dacrymenone (1) were observed at concentrations up to $100 \mu \mathrm{g} / \mathrm{ml}$, sporogen A01 (4), a closely related eremophilane containing an additional oxirane ring is highly cytotoxic $\left(\mathrm{IC}_{50}: 1-5 \mu \mathrm{g} / \mathrm{ml}\right)$ (Schneider et al., 1997). VM 3298-2 (2) is cytotoxic towards Colo-320, HL-60, and L1210 cells (see Fig. 5) with $\mathrm{IC}_{50}$ values of $10 \mu \mathrm{g} / \mathrm{ml}(44 \mu \mathrm{M})$ and $5 \mu \mathrm{g} / \mathrm{ml}(22 \mu \mathrm{M})$ for HL-60 and L1210 cells.

Fig. 6 shows the effects of $\mathbf{2}$ on protein, chitin, DNA and RNA syntheses of Nematospora coryli. Only weak and partial inhibition of the macromolecule syntheses was observed pointing to an indirect interference of VM 3298-2 (2) with these metabolic pathways.
Table I. Minimal inhibitory concentration (MIC) of dacrymenone (1) and VM 3298-2 (2) in the serial dilution assay.

\begin{tabular}{|c|c|c|}
\hline \multirow[t]{2}{*}{ Organism } & \multicolumn{2}{|c|}{$\operatorname{MIC}[\mu \mathrm{g} / \mathrm{ml}]$} \\
\hline & 1 & 2 \\
\hline $\begin{array}{l}\text { Bacteria } \\
\text { Arthrobacter citreus }\end{array}$ & & \\
\hline $\begin{array}{l}\text { Arthrobacter citreus } \\
\text { Bacillus brevis }\end{array}$ & $\begin{array}{l}100 \\
100\end{array}$ & - \\
\hline Bacillus subtilis & - & - \\
\hline Micrococcus luteus & 25 & - \\
\hline Mycobacterium phlei & 100 & - \\
\hline Escherichia coli & - & - \\
\hline Salmonella thyphimurium & 100 & - \\
\hline \multicolumn{3}{|l|}{ Yeasts } \\
\hline Candida glabrata & - & 100 \\
\hline Candida krusei & - & 100 \\
\hline Candida parapsilosis & - & 25 \\
\hline Nadsonia fulvescens & - & - \\
\hline Nematospora coryli & - & 50 \\
\hline Rhodotorula glutinis & - & 50 \\
\hline Saccharomyces cerevisiae is 1 & - & 10 \\
\hline S. cerevisiae $\alpha S 288 c$ & - & 50 \\
\hline \multicolumn{3}{|l|}{ Filamentous fungi } \\
\hline Absidia glauca (+) & - & - \\
\hline Absidia glauca (-) & - & - \\
\hline Alternaria porri & - & - \\
\hline Ascochyta pisi & - & - \\
\hline Aspergillus ochraceus & 8 & 50 \\
\hline Cladosporium cladosporioides & 100 & 100 \\
\hline Fusarium fujikuroi & - & - \\
\hline Fusarium oxysporum & - & 100 \\
\hline Mucor miehei & - & 100 \\
\hline Paecilomyces variotii & - & - \\
\hline Penicillium islandicum & - & - \\
\hline Penicillium notatum & - & 100 \\
\hline Zygorhynchus moelleri & - & 50 \\
\hline
\end{tabular}

- = no effects up to $100 \mu \mathrm{g} / \mathrm{ml}$.

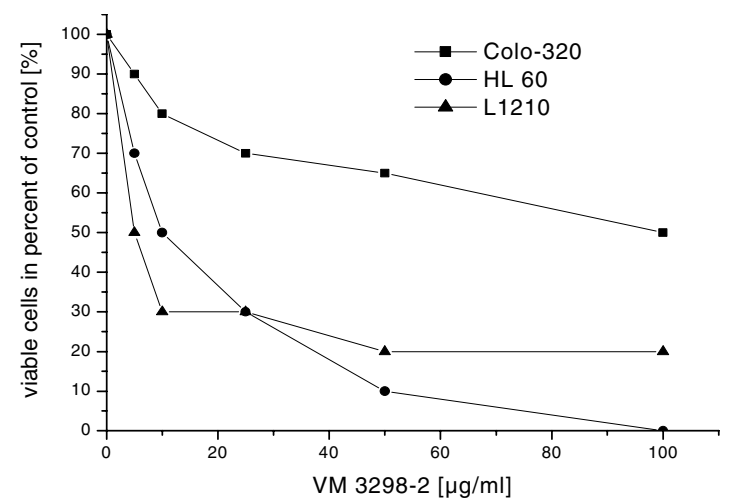

Fig. 5. Cytotoxic effects of VM 3298-2 (2) on Colo-320, HL-60 and L1210 cells.

Controls (100\%): Colo-320, 4.3 $10^{5}$; HL 60, 3.8 $10^{5}$; L $1210,3.7 \cdot 10^{5}$ cells $/ \mathrm{ml}$. 


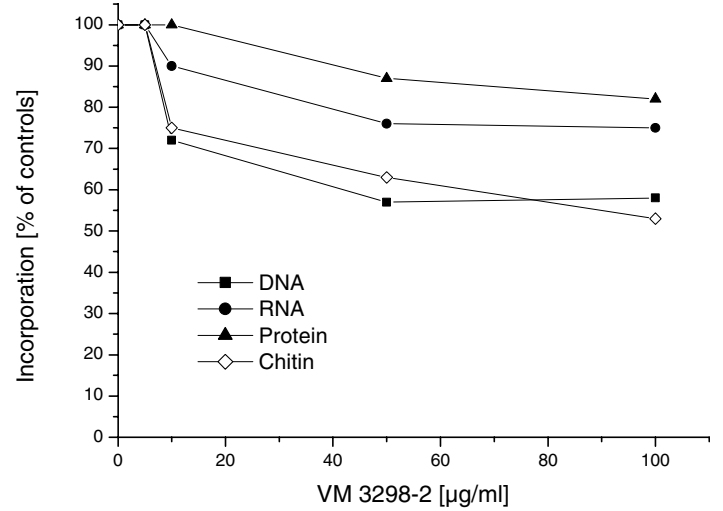

Fig. 6. Effects of VM 3298-2 (2) on protein, chitin, DNA and RNA syntheses of Nematospora coryli. Incorporation into the controls $(100 \%):{ }^{14} \mathrm{C}$-adenine (DNA), $10.921 \mathrm{cpm} ;{ }^{14} \mathrm{C}$-uridine (RNA), $44.222 \mathrm{cpm} ;{ }^{14} \mathrm{C}$-leucine (proteins), $9.005 \mathrm{cpm} ;{ }^{14} \mathrm{C}-\mathrm{N}$-acetyl-glucosamine (chitin) $476 \mathrm{cpm}$.

Anke H., Bergendorff O., and Sterner O. (1989), Assays of the biological activities of guaiane sesquiterpenoids isolated from the fruit bodies of edible Lactarius species. Food Chem. Toxicol. 27, 393-397.

Moulé Y., Moreau S., and Bousquet J. F. (1977), Relationships between the chemical structure and the biological properties of some eremophilane compounds related to PR Toxin. Chem.-Biol. Interactions 17, 185-192.

Nishida F., Mori Y., Sonobe C., Suzuki M., Meevootisom V., Flegel T. W., Thebtaranonth Y., and Intararuangsorn S. (1991), Structure elucidation of glycosidic antibiotics glykenins from Basidiomycetes sp. III. Structure of glykenin IV. J. Antibiot. 44(5), 541-545.

Nishida F., Nishimura M., Harada K., Suzuki M., Meevootisom V., Flegel T. W., Thebtaranonth Y., and Intararuangsorn S. (1994), Structure elucidation of glykenin glycosidic antibiotics from Basidiomycetes $\mathrm{sp}$. V. High-performance liquid chromatographic separation of components of glykenin. J. Chromatogr. A 664 $195-202$.
Due to the phytotoxic effects described for related eremophilans e. g. petasol (5) and 1-hydroxypetasol, dacrymenone (1) was applied to barley leafs. $5 \mathrm{~cm}$ long leaf cuts of 10-day-old seedlings of Hordeum sativum were placed on microscope slides and fixed with a tape. $1(1-5 \mu \mathrm{mol})$ was placed on a puncture wound $\left(9 \mathrm{~mm}^{2}\right.$ of leaf surface) and then incubated in a plastic box with $100 \%$ humidity at $28^{\circ} \mathrm{C}$ and a 16 -h light period for $72 \mathrm{~h}$

Concentrations as low as $1 \mu \mathrm{M}$ produced green islands $\left(20 \mathrm{~mm}^{2}\right)$ and necrotic lesions on leafs, whereas in a similar assay petasol was reported to produce green islands on monocot leafs at much higher concentrations $(10-20 \mu \mathrm{M}$; F. Sugawara et al., 1993).

Pfefferle W., Anke H., Bross M., Steffan B., Vianden R. and Steglich W. (1990), Asperfuran, a novel antifungal metabolite from Aspergillus oryzae. J. Antibiot. 43, 648-654.

Schneider G., Anke H., and Sterner O. (1997), New secondary metabolites from a mycophilic Hansfordia species. Nat. Prod. Lett. 10, 133-138.

Sugawara F., Hallock Y. F., Bunkers G. D., Kenfield D. S., Strobel G., and Yoshida S. (1993), Phytoactive eremophilanes produced by the weed pathogen Drechslera gigantea. Biosci. Biotech. Biochem. 57, 236-239.

Wunder A. (1995), Dissertation. University of Kaiserslautern, Germany.

Zapf S., Hoßfeld M., Velten R., and Steglich W. (1995), Darlucins A and B, new isocyanide antibiotics from Sphaerellopsis filum (Darluca filum). J. Antbiot. 48, 36-41. 